\title{
Comparison of Chromatographic and Titrimetric Methods for the Determination of the $\alpha$-amino Nitrogen in Standard Solution and Fish Protein Hydrolysates
}

\author{
Haiyan Wang ${ }^{1}$, Fenglan Zhang ${ }^{1}$, Jin Cao ${ }^{1}$, Qingsheng Zhang ${ }^{1} \&$ Zhirong Chen ${ }^{1}$ \\ ${ }^{1}$ National Institutes for Food and Drug Control, Beijing, China \\ Correspondence: Haiyan Wang, National Institutes for Food and Drug Control, Beijing 100050, China. Tel: \\ 86-106-709-5948. E-mail: tobaccowhy@126.com
}

Received: August 27, 2012 Accepted: September 17, 2012 Online Published: October 29, 2012

doi:10.5539/jfr.v1n4p174 URL: http://dx.doi.org/10.5539/jfr.v1n4p174

\begin{abstract}
Two analytical methods, reverse phase high-performance liquid chromatography (RP-HPLC) and formol titration, were compared for their accuracy and precision for the determination of $\alpha$-amino nitrogen ( $\alpha$-AN) concentration in fish protein hydrolysates. The result showed that, when tested with pure amino acid solutions, RP-HPLC method had a better standard deviation (S. D.), coefficient of variation (C. V.), and standard error (S. E.) but a poorer recovery rate compared with formol titration technique. The observed $\alpha$-AN value by RP-HPLC has good coincidence with the actual $\alpha$-AN value and their correlation coefficient (r) is 0.9981 , which was close to the $\mathrm{r}$ value (0.9995) between the $\alpha$-AN by formol titration and the actual $\alpha$-AN. However, when tested with protein hydrolysates, the $\alpha$-AN obtained from RP-HPLC technique were significantly $(\mathrm{p}<0.05)$ lower than that from formol titration for the same sample. Therefore, the formol titration method can be used as a quick screening method to assess the quality fish hydrolystaes.
\end{abstract}

Keywords: $\alpha$-amino nitrogen, RP-HPLC, formol titration, protein hydrolysates

\section{Introduction}

Enzymatic hydrolysis is widely used to improve functional or nutritional properties of food proteins (Mahmoud, 1994; Kim \& Wijesekara, 2010). For example, protein hydrolysates with different degree of hydrolysis values (DH) can be used as flavourings having unique flavors and aromas (Su, Ren, Yang, Cui, \& Zhao, 2011). Fish sauce, a traditional seasoning popular in the Orient, is the hydrolysate of fish protein by fungal proteases and amylases (Chou \& Ling, 1998). During the processing of fish sauce, soluble nitrogenous compounds such as amino acids and peptides are formed (Kiesvaara, 1975). The amount of new amino acids formed is very important to the flavor of the sauce. Generally, the term "amino acids" refers to $\alpha$-amino acids with the general formula H2NCHRCOOH, where R is an organic substituent (Sakami \& Harrington, 1963). The concentration of $\alpha$-amino nitrogen $(\alpha-\mathrm{AN})$ is often used as the quality indicator for fish sauce products according to both the national standard of China and the Japanese Agricultural Standard (JAS) (Chinese National Standard, 1994; Yokotsuka, 1986). Fish sauce can be graded by $\alpha$-AN concentration and the higher the $\alpha$-AN concentration, the better the quality.

Formol-titration is a rapid method for detecting the amino group of amino acids and has been found to be very convenient and accurate. Formaldehyde is added to the solution and reacts with the $\mathrm{NH}_{3}{ }^{+}$group of protein chain, which liberates an equivalent quantity of $\mathrm{H}^{+}$, which may then be estimated by titration with $\mathrm{NaOH}$ (Northrop, 1926). This method is convenient and rapid, and is considered useful in the determination of $\alpha$-AN concentration. There are also other methods to assay the $\alpha$-AN concentration. For example, RP-HPLC can be used to analyze the contents of free amino acids (FAA) in solution and the $\alpha$-AN concentration can be indirectly obtained by summing up the total concentration of FAA. FAAs indirectly contribute to the development of aroma of fish protein hydrolysates since they are precursors of many volatile compounds. The flavor of fish protein hydrolysates can be influenced by single amino acid, for example, by glutamic acid for umami and by aspartic acid for sweetness (Kim, Shahidi, \& Heu, 2003). Since the amino acid composition changes with different hydrolysis periods, RP-HPLC method is also applied to determine the quantities of each individual amino acid (Je, Park, Jung, \& Kim, 2005). 
Our research group have done a lot of work on fish protein hydrolysates (Ren et al., 2008a \& 2008b), and during our routine assay, we have found that the $\alpha$-AN molar concentration obtained by RP-HPLC was far less than that by formol titration for the same sample. To learn more about the discrepancy between these two methods, the current study compared the accuracy and precision of the RP-HPLC and the formol-titration method for the determination of $\alpha$-AN in fish protein hydrolysates. Also, a model was designed to explain the changes that occur during the hydrolysis, which would be useful for understanding protein proteolysis and provide some guidance to those producing fish sauce.

\section{Method}

\subsection{Materials}

Healthy live grass carp (Ctenopharyngodon idellus, $822 \pm 147 \mathrm{~g}$ in weight and $40.8 \pm 2.8 \mathrm{~cm}$ in length) were obtained from a local market in Guangzhou, China. Grass carps (without head, tail, skin, bone, internal organs and blood) were filleted and minced in a MM12 mincer (Shaoguan Food Machine Co., Shaoguan, Guangdong, China). The minced material was frozen and stored at $-20^{\circ} \mathrm{C}$ for further use up to three weeks. Four proteases were obtained from Novo Nordisk Co. (Beijing, China) and Mingyuan Co. (Guangzhou, China). They were respectively Alcalase $2.4 \mathrm{~L}$, papain, trypsin, pancreatin 6.0. The amino acid standard mixture, phenylisothiocyanate (PITC), triethylamine (TEA) and acetonitrile were all HPLC-grade and were purchased from Sigma (Sigma-Aldrich China Mainland, Beijing, China). All other reagents were analytical-grade.

\subsection{Sample Preparation}

\subsubsection{Standard Amino Acid Solutions}

The standard amino acid mixture consists of 18 amino acids: Asp, Glu, Ser, Gly, His, Arg, Thr, Ala, Pro, Tyr, Val, Met, Cys, Ile, Leu, Trp, Phe and Lys. The powder was first dissolved with a few drops of $6 \mathrm{~mol} / \mathrm{L} \mathrm{HCI}$ and then diluted to 37.5, 50.0, 75.0, 100, 150, 200, 225, 250 and $300 \mathrm{mmol} / \mathrm{L}$, respectively, with deionized water.

\subsubsection{Preparation of Grass Carp Protein Hydrolysates}

The frozen grass carp muscles $(400 \mathrm{~g})$ were thawed and mixed with deionized water $(400 \mathrm{ml})$. The mixture was divided into four fractions of about $200 \mathrm{~g}$ each. Each of the fractions was adjusted to the required $\mathrm{pH}$ optimum for the enzyme with $0.01 \mathrm{~mol} / \mathrm{L} \mathrm{NaOH}$ and heated in a water bath to the enzyme's optimum temperature (Table 1). Alcalase $2.4 \mathrm{~L}$, papain, trypsin and pancreatin 6.0 were dissolved in deionized water and added in the proper proportions based on their activity to gain equal enzyme to substrate ratio [E/S] (Table 1). The hydrolysis reaction was performed in a shaking incubator (New Brunswick Scientifics C24, Beijing, China). Three hydrolysis time intervals ( $1 \mathrm{~h}, 2 \mathrm{~h}$ and $4 \mathrm{~h}$ ) were studied. At the end of the hydrolysis period, the mixtures were heated in boiling water for $10 \mathrm{~min}$ to inactivate the proteases. The mixtures were cooled to room temperature and centrifuged in a GL-21M refrigerated centrifuge (Xiangyi Instrument Co. Ltd., Changsha, China) at $4800 \mathrm{~g}$ for $30 \mathrm{~min}$ and the supernatant was lyophilized and stored in a desiccator for further use.

Table 1. Parameters for the enzymatic hydrolysis of grass carp protein

\begin{tabular}{llcll}
\hline Proteases & Activity $(\mathrm{U} / \mathrm{g})$ & Incubation temperature $\left({ }^{\circ} \mathrm{C}\right)$ & $\mathrm{pH}$ & {$[\mathrm{E} / \mathrm{S}]^{\mathrm{a}}(\mathrm{w} / \mathrm{w})$} \\
\hline Alcalase $2.4 \mathrm{~L}$ & $6.9 \times 10^{4}$ & 60.0 & 7.8 & 0.15 \\
Papain & $2.4 \times 10^{4}$ & 50.0 & 7.0 & 0.15 \\
Pancreatin & $6.0 \times 10^{4}$ & 55.0 & 7.0 & 0.10 \\
Trypsin & $3.0 \times 10^{4}$ & 55.0 & 7.0 & 0.20 \\
\hline
\end{tabular}

${ }^{\text {a }}$ Enzyme to substrate ratio

\subsection{Analytical Methods}

1) $\alpha$-AN assay using RP-HPLC. The RP-HPLC was done using a Waters system (Milford MA, USA) with a Pico.Tag ${ }^{\circledR}$ column $(3.9 \times 150 \mathrm{~mm})$. Prior to running, the amino acids were derivatized with PITC (Puig-Deu \& Buxaderas, 1994). First a TEA solution with TEA-water-ethanol (1:2:2) was added to samples and evaporated to dryness under vacuum. Then PITC solution including PITC-ethanol-TEA-water $(1: 7: 1: 1)$ was added to the dried samples and reacted at room temperature for $20 \mathrm{~min}$. After loading samples onto the column, elution was carried out using a pH 6.4 sodium acetate buffer (eluent A) and $60 \%$ (v/v) aqueous acetonitrile (eluent B). A gradient elution mode was used with the following condition: 0-10 min, linear gradient 0-46\% B; 10-12 min, linear gradient $46-100 \% \mathrm{~B}$; $12-15 \mathrm{~min}, 100 \% \mathrm{~B}$; the flow rate: $1 \mathrm{~mL} / \mathrm{min}$; the column temperature: $38^{\circ} \mathrm{C}$; the 
detection wavelength: $254 \mathrm{~nm}$.

In theory, the total molar concentration of free amino acids in pure amino acid solution (including no proline) should equal to the AN molar concentration, because each of the 20 amino acids in protein contains only one $\alpha$-amino nitrogen except proline which contains no $\alpha$-amino nitrogen, contributes only about $7 \%$ of the AN. Generally, proline usually existed in fish skin and there is very few proline in fish protein, therefore, the sum of the molar concentration of each detected amino acid could be considered equal to the total $\alpha$-AN concentration of the sample. The total $\alpha$-AN concentration $(\mathrm{mmol} / \mathrm{L})$ of the sample was obtained by summing up the molar concentration of each detected amino acid.

2) $\alpha$-AN assay using formol titration. The assay was done using a modification of the method described by Biehl et al. (Biehl, Brunner, Passern, Quesnel \& Adomako, 1985). Five $\mathrm{mL}$ of the freeze-dried protein hydrolysate (1 $\mathrm{mg} / \mathrm{mL}$ ) was mixed with $50 \mathrm{~mL}$ of deionized water. The solution was adjusted to $\mathrm{pH} 8.2$ with $\mathrm{NaOH}$ (around 0.1 $\mathrm{M})$ and then $10 \mathrm{~mL}$ of $35 \%(\mathrm{w} / \mathrm{w})$ formalin $(\mathrm{pH} 8.2)$ was added. The $\mathrm{pH}$ value of the solution went down due to the addition of formol. The titration using $\mathrm{NaOH}$ was done until the $\mathrm{pH}$ of the solution was 9.20. The concentration of $\alpha$-AN was calculated using the following equation:

$$
C_{\alpha-\mathrm{AN}}(\mathrm{mM})=\frac{\Delta \mathrm{V} \times \mathrm{n} \times 10^{3}}{V}
$$

where $\Delta \mathrm{V}$ is the volume in $\mathrm{mL}$ of $\mathrm{NaOH}$ used for the titration; $\mathrm{n}(\mathrm{mol} / \mathrm{L})$ is the molar concentration of the $\mathrm{NaOH}$ solution; and $V(\mathrm{~mL})$ is the sample volume.

\subsection{Statistical Tests}

The results and samples were subjected to statistics analysis carried out using SPSS 10.0 statistical software. Significant levels were defined as probabilities of 0.05 .

\section{Results and Discussion}

\subsection{Comparison of the RP-HPLC and Formol Titration Methods}

Table 2 showed the concentration of $\alpha$-AN in a standard amino acid solution using RP-HPLC and formol titration, respectively. The statistical method proposed by Martin et al. was used to compare the accuracy of the two methods (Martín \& Luna del Castillo, 1990). The accuracy was expressed as a percentage of recovery rate. Taking into account the arithmetic mean of the five measurements obtained for each concentration (Table 2), the formol titration method gave a better recovery rate (closer to $100 \%$ in all tested samples) compared with the RP-HPLC technique. Therefore, the formol titration method was considered to have a greater level of accuracy than RP-HPLC. The standard deviation (S.D.), the coefficient of variation (C.V.) and the standard error (S.E.) are tested. As shown in Table 3, the S.D. values, as well as C.V. and S.E. values with RP-HPLC were all smaller than for the formol titration method, which indicated that the RP-HPLC method was more precise than the formol titration method. Therefore, the conclusion was that for the determination of $\alpha$-AN concentration in a solution of amino acids, the formol titration was more accurate but less precise than the RP-HPLC technique.

Table 2. The $\alpha$-AN concentration in standard pure amino acid solutions determined by the RP-HPLC method and the formol titration method. Values in this table were the means of five determinations

\begin{tabular}{|c|c|c|c|c|}
\hline \multicolumn{2}{|c|}{$\alpha$-AN concentration by formol titration } & \multirow{2}{*}{$\begin{array}{l}\text { Real value }^{\mathrm{a}} \\
(\mathrm{mmol} / \mathrm{L})\end{array}$} & \multicolumn{2}{|c|}{$\alpha$-AN concentration by RP-HPLC } \\
\hline $\begin{array}{l}\text { Recovery } \\
(\%)\end{array}$ & $\begin{array}{l}\text { Mean concentration } \\
(\mathrm{mmol} / \mathrm{L})\end{array}$ & & $\begin{array}{l}\text { Mean concentration } \\
(\mathrm{mmol} / \mathrm{L})\end{array}$ & $\begin{array}{c}\text { Recovery } \\
(\%)\end{array}$ \\
\hline $103.47 \pm 5.04$ & $38.80 \pm 1.89$ & 37.50 & $35.16 \pm 1.08$ & $93.76 \pm 2.88$ \\
\hline $99.20 \pm 4.04$ & $49.60 \pm 2.02$ & 50.00 & $48.70 \pm 0.96$ & $97.40 \pm 1.92$ \\
\hline $99.12 \pm 3.81$ & $74.34 \pm 2.86$ & 75.00 & $69.11 \pm 1.42$ & $92.15 \pm 1.89$ \\
\hline $97.80 \pm 3.01$ & $97.80 \pm 3.01$ & 100.00 & $90.26 \pm 2.01$ & $90.26 \pm 2.01$ \\
\hline $97.07 \pm 1.80$ & $145.60 \pm 2.70$ & 150.00 & $145.02 \pm 2.65$ & $96.68 \pm 1.77$ \\
\hline $98.65 \pm 1.89$ & $197.30 \pm 3.78$ & 200.00 & $184.90 \pm 2.87$ & $92.45 \pm 1.44$ \\
\hline $98.31 \pm 1.88$ & $221.20 \pm 4.24$ & 225.00 & $203.40 \pm 3.02$ & $90.40 \pm 1.34$ \\
\hline $99.04 \pm 1.95$ & $247.60 \pm 4.87$ & 250.00 & $237.85 \pm 3.76$ & $95.14 \pm 1.50$ \\
\hline $96.43 \pm 1.96$ & $289.29 \pm 5.87$ & 300.00 & $283.62 \pm 4.01$ & $94.54 \pm 1.34$ \\
\hline
\end{tabular}

${ }^{a}$ Real value means the actual $\alpha$-AN concentration in each standard pure amino acid solution. 
Table 3. The standard deviation (S.D.), the coefficient of variation (C.V.) and the standard error (S.E.) for the $\alpha$-AN data in standard pure amino acid solutions determined by the RP-HPLC technique and the formol titration method

\begin{tabular}{cccccc}
\hline \multicolumn{2}{c}{$\begin{array}{c}\text { Standard deviation } \\
\text { (S.D.) }\end{array}$} & \multicolumn{2}{c}{$\begin{array}{c}\text { Coefficient of Variation (\%) } \\
\text { (C.V.) }\end{array}$} & \multicolumn{2}{c}{$\begin{array}{c}\text { Standard error } \\
\text { (S.E.) }\end{array}$} \\
\hline RP-HPLC & Formol titration & RP-HPLC & Formol titration & RP-HPLC & Formol titration \\
\hline 0.67 & 0.95 & 1.13 & 2.46 & 0.30 & 0.43 \\
0.20 & 0.68 & 0.55 & 1.37 & 0.09 & 0.30 \\
0.53 & 0.83 & 0.75 & 1.12 & 0.24 & 0.37 \\
0.22 & 0.43 & 0.27 & 0.44 & 0.10 & 0.19 \\
0.46 & 0.58 & 0.30 & 0.45 & 0.21 & 0.26 \\
0.68 & 0.95 & 0.33 & 0.49 & 0.31 & 0.44 \\
0.25 & 0.93 & 0.14 & 0.42 & 0.11 & 0.42 \\
0.60 & 0.48 & 0.28 & 0.19 & 0.27 & 0.22 \\
0.72 & 1.31 & 0.29 & 0.45 & 0.32 & 0.59 \\
\hline
\end{tabular}

However, the results obtained thus far were not conclusive. Further statistical analysis was still needed. Firstly, a correlation analysis was also done based on the determination of $\alpha$-AN concentrations in the standard pure amino acid solution. As Table 4 shows, the $\alpha$-AN value determined by the RP-HPLC technique has good coincidence with the real $\alpha$-AN value and their correlation coefficient $(r)$ is 0.9981 . The correlation coefficients $(r)$ between the $\alpha$-AN value determined by the formol titration method and the real $\alpha$-AN value is 0.9995 . Therefore, both methods showed a strong linear relationship between the tested $\alpha$-AN values. Since the $r$ values for the two methods were close to each other, it is not possible to state that either technique is better than the other.

Table 4. Correlation coefficients $(r)$ analysis for $\alpha$-AN determined by RP-HPLC or formol titration versus the real value in standard pure amino acid solution

\begin{tabular}{ccc}
\hline Data for correlation analysis & $\begin{array}{c}\text { Correlation } \\
\text { coefficient }(r)\end{array}$ & Linear equation \\
\hline$\alpha$-AN by RP-HPLC $v$ s. the real value & 0.9981 & $\mathrm{y}=0.9389-0.5253 \mathrm{x}$ \\
$\alpha$-AN by formol titration $v s$. the real value & 0.9995 & $\mathrm{y}=0.9704+1.669 \mathrm{x}$ \\
\hline
\end{tabular}

Secondly, a two-sample comparison test was preformed, as proposed by Porretta et al. and Quesada et al. (Porretta \& Sandei, 1991; Quesada, Villalón, López \& Loópez, 1995). The Kolmogorov-Smirnov test was first applied to determine if the distribution of results from both methods were normal and thus a $t$-test could be applied or whether, a non-parametric test would be required. The results of Kolmogorov-Smirnov test at $95 \%$ confidence showed that the distribution of $\alpha$-AN data determined by RP-HPLC were normal $(p=0.950>0.05)$ and the data determined by RP-HPLC were also normal distribution $(p=0.967>0.05)$. Therefore, the $t$-test could be used. The results of the $t$-tests showed that there was no significant difference $(p>0.05)$ between the real $\alpha$-AN concentration and that found by RP-HPLC or formol titration of the standard amino acid solutions. The box-and-whisker plot of the $t$-tests (Figure 1) indicated that based on the median, the lower quartile and the upper quartile, the $\alpha$-AN concentration values determined by the formol titration method had a more similar data distribution to the real values. Therefore, the formol titration was considered to be more accurate than RP-HPLC. 


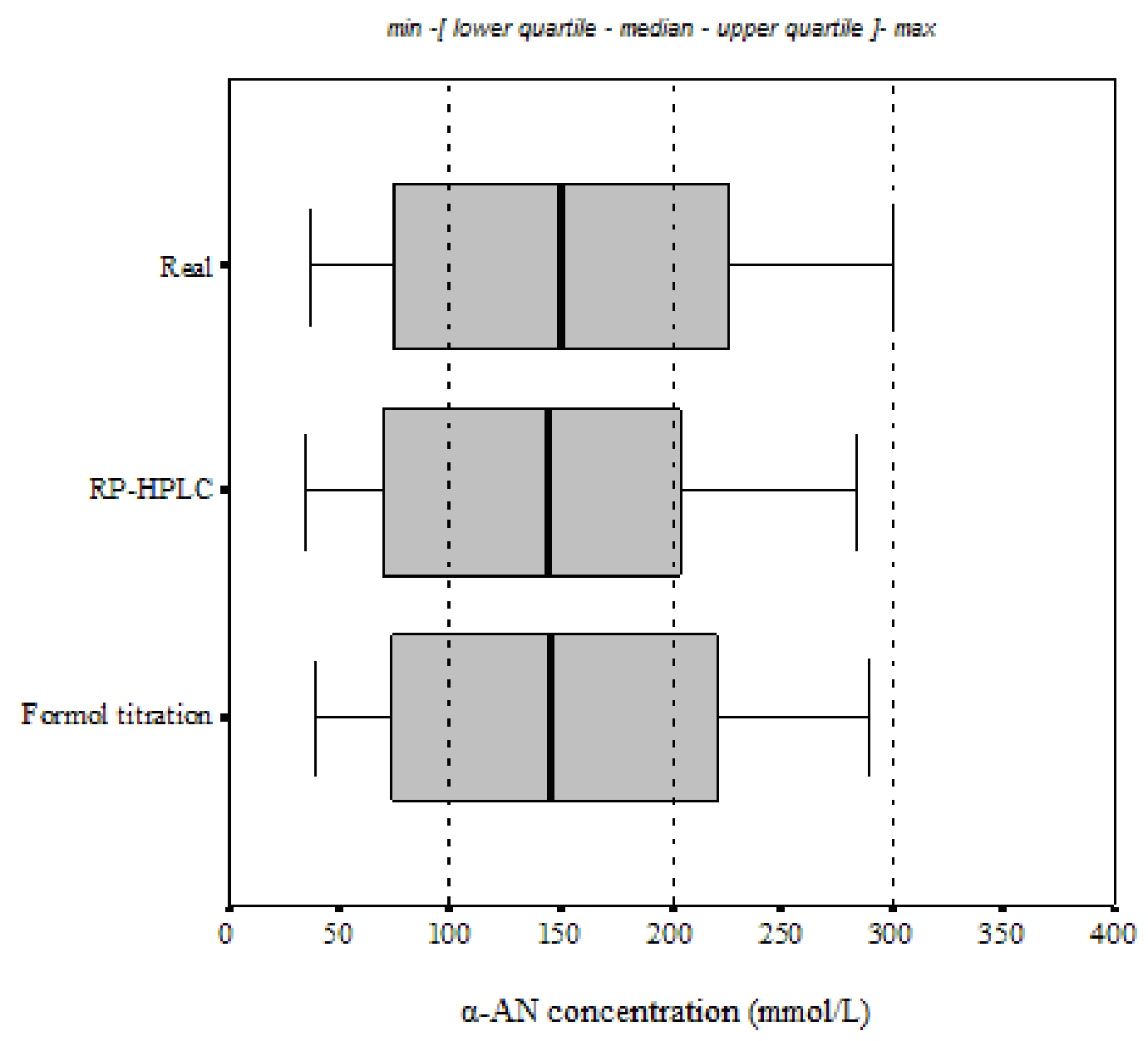

Figure 1. Box-and-whisker plot

Description: It was constructed based on the $t$-test of the $\alpha$-AN concentrations in a series of standard amino acid solutions determined by the RP-HPLC technique and the formol titration method. The real concentrations of these standard amino acid solutions were respectively $37.5,50.0,75.0,100,150,200,225,250$ and $300 \mathrm{mmol} / \mathrm{L}$.

\subsection{Applications in the Determination of $\alpha-A N$ in Protein Hydrolysates}

The $\alpha$-AN concentration of grass carp protein hydrolysates prepared by Alcalase $2.4 \mathrm{~L}$, papain, trypsin and pancreatin 6.0 was determined by RP-HPLC and formol titration. The chromatogram of the RP-HPLC analysis for the trypsin hydrolysates is given as an example and is shown in Figure 2 (other chromatograms not shown). The comparison between the RP-HPLC and formol titration result is given in Table 5. It was found that the $\alpha$-AN molar concentration data obtained from RP-HPLC analysis were much lower than those determined by formol titration. As far as each paired-samples is concerned, the difference between the two methods is statistically significant $(p<0.05)$ as proven by the paired $t$-test. Also, an increase in the difference was observed with longer hydrolysis time intervals $(2 \mathrm{~h}$ and $4 \mathrm{~h}$ ) for the hydrolysates prepared by the same protease. The difference may probably due to the difference of accuracy and precise between these two methods, however, this could not be the only explanation for the cause. The following discussion was focused on the difference between the mechanisms of these two methods on $\alpha$-AN determination. 


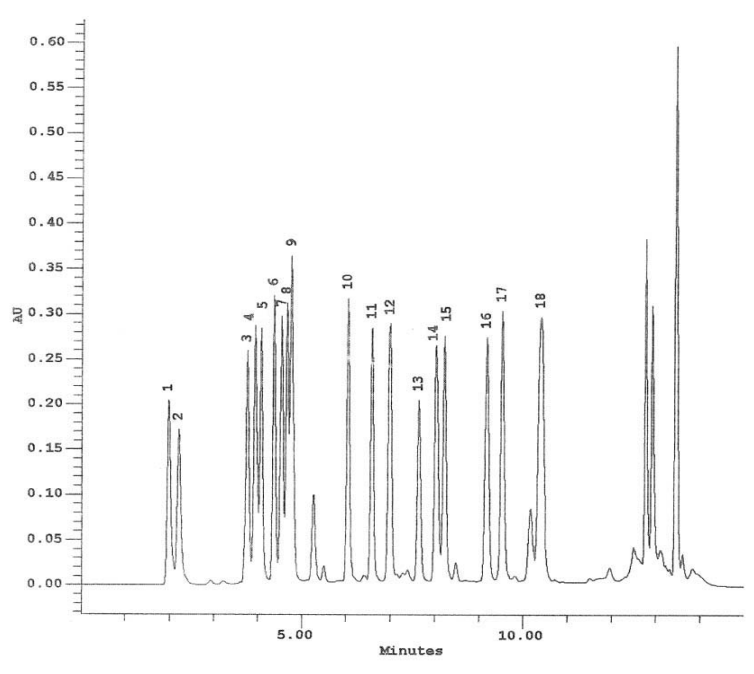

(A)

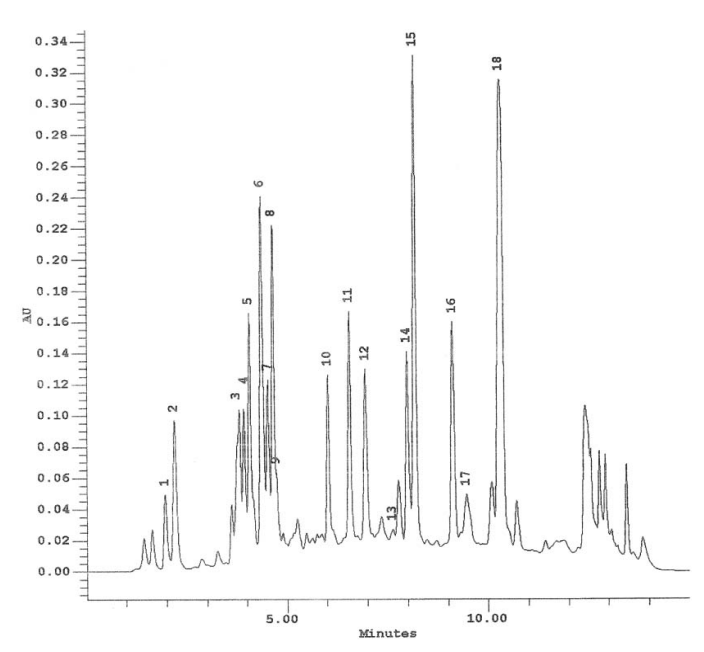

(C)

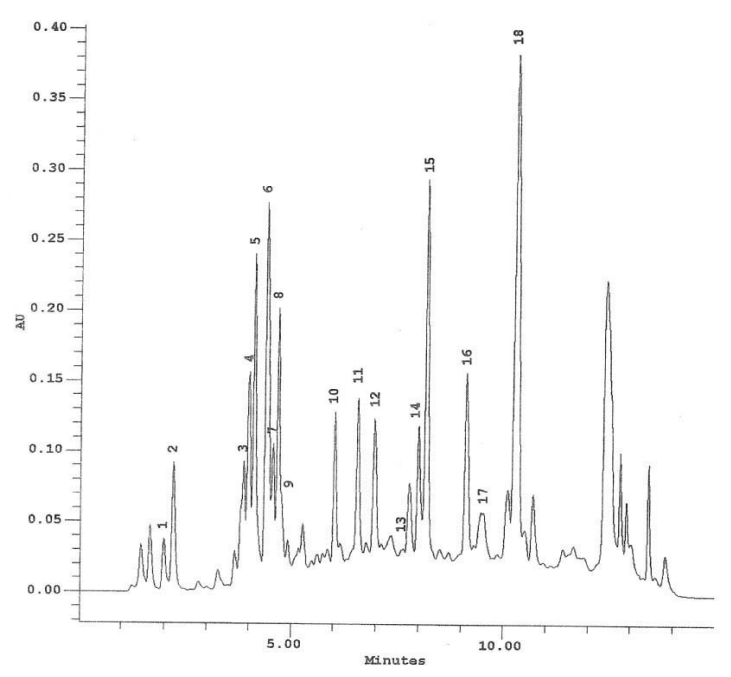

(B)

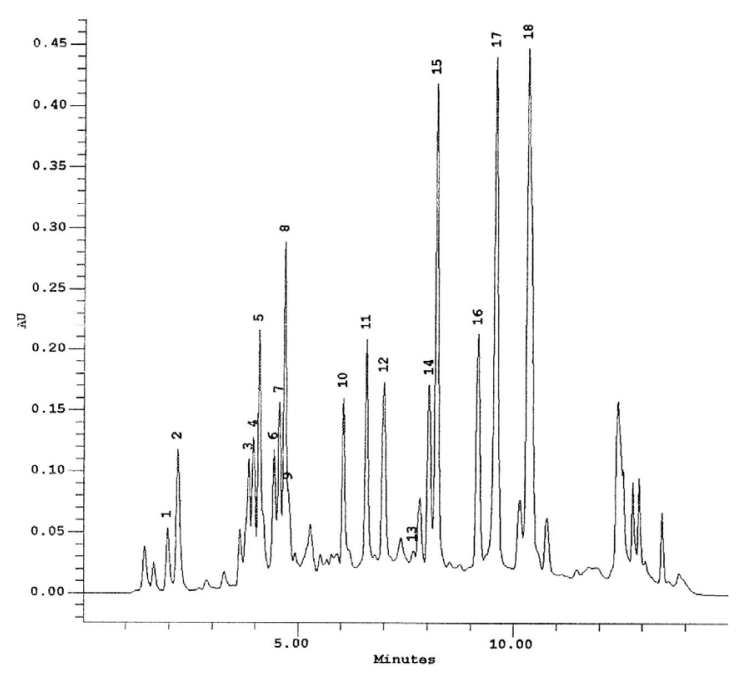

(D)

Figure 2. RP-HPLC chromatogram of free amino acids determination in standard amino acid solution and fish protein hydrolysates prepared with Trypsin

Description: A: standard amino acid solution; B: Trypsin hydrolysates (1 h); C: Trypsin hydrolysates $(2 \mathrm{~h})$; D: Trypsin hydrolysates $(4 \mathrm{~h})$. The numbers 1-18 indicate the peak of the different amino acids (1-Asp, 2-Glu, 3-Ser, 4-Gly, 5-His, 6-Arg, 7-Thr, 8-Ala, 9-Pro, 10-Tyr, 11-Val, 12-Met, 13-Cys, 14-Ile, 15-Leu, 16-Trp, 17-Phe, 18-Lys). 
Table 5. Concentration of $\alpha-\mathrm{AN}$ (mmol/L) of fish protein hydrolysates analyzed by the RP-HPLC technique and the formol titration method

\begin{tabular}{cccc}
\hline \multirow{2}{*}{ Hydrolysates } & \multicolumn{2}{c}{$\alpha$-AN concentration } & \multirow{2}{*}{ Difference } \\
\cline { 2 - 3 } & RP-HPLC & Formol titration & \\
\hline Alcalase (1 h) & $10.64 \pm 0.12$ & $51.44 \pm 0.47$ & 40.80 \\
Alcalase (2 h) & $38.12 \pm 0.44$ & $78.95 \pm 0.51$ & 40.83 \\
Alcalase (4 h) & $61.33 \pm 0.36$ & $116.91 \pm 0.76$ & 55.58 \\
Papain (1 h) & $27.16 \pm 0.32$ & $67.89 \pm 0.68$ & 40.73 \\
Papain (2 h) & $38.92 \pm 0.46$ & $80.36 \pm 0.56$ & 41.44 \\
Papain (4 h) & $54.02 \pm 0.53$ & $104.22 \pm 0.91$ & 50.20 \\
Trypsin (1 h) & $14.25 \pm 0.11$ & $65.34 \pm 0.38$ & 51.09 \\
Trypsin (2 h) & $36.18 \pm 0.55$ & $91.12 \pm 0.81$ & 54.94 \\
Trypsin (4 h) & $55.99 \pm 0.62$ & $114.15 \pm 0.74$ & 58.16 \\
Pancreatin (1 h) & $71.99 \pm 0.43$ & $115.39 \pm 0.62$ & 43.40 \\
Pancreatin (2 h) & $87.59 \pm 0.31$ & $132.14 \pm 0.59$ & 44.55 \\
Pancreatin (4 h) & $114.50 \pm 0.68$ & $167.50 \pm 1.02$ & 53.00 \\
\hline
\end{tabular}

The proteolytic hydrolysis of protein yields peptides chains of different lengths from just a little shorter than the original peptide chain down to amino acids (Kairiyama \& Narvaiz, 1997). Using the formol titration method (Figure 3), free amino acid which contains one $\alpha-\mathrm{NH}_{2}-$ group could only react with one formol molecule. In terms of peptide, regardless of the size of the peptide, it will react with one formol molecule since it still has one $\alpha-\mathrm{NH}_{2}$ - group. Thus, the formol method actually measures the total $\alpha$-AN concentration of free amino acids, oligopeptides and polypeptides in protein hydrolysates. On the other hand, only the free amino acids are measured using the RP-HPLC method used in this work. Apparently, the presence of oligo- or poly- peptides in protein hydrolysates was the main reason for the difference of these two methods on the determination of $\alpha$-AN. Therefore, the amount of oligo- or poly- peptides in the hydrolysates could influence the results obtained from these two methods. The more the peptides were, the larger the difference would be.

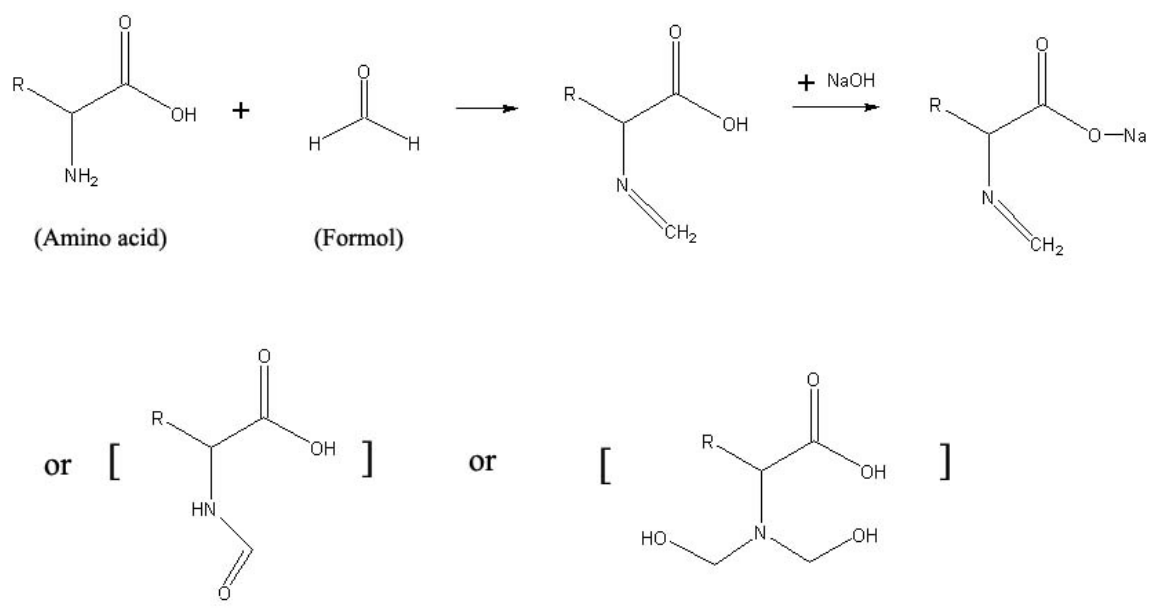

Figure 3. The mechanism of the formol titration method for determination of $\alpha$-AN

Here, a model was built to explain why the difference existed and why the discrepancy became larger during the process of proteolysis (Figure 4). The four proteases used in the present work, Alcalase $2.4 \mathrm{~L}$, papain, trypsin and pancreatin 6.0, are endopeptidases (Aspmo, Horn, \& Eijsink, 2005; Lopes \& Terra, 2003; Zapelena, Ansorena, 
Zalacain, Astiasarán, \& Bello, 1998), which break peptide bonds of nonterminal amino acids (i.e., within the molecule) rather than the peptide bonds at end pieces. Therefore, at the beginning of the hydrolysis, large protein molecules were broken down by endopeptidases to mostly poly- or oligo- peptides, while very few additional free amino acids were generated by the hydrolysis (stage I). Therefore, the $\alpha$-AN concentration obtained by formol titration was larger than that by RP-HPLC due to the presence of peptides.

With the proceeding of hydrolysis, protein molecules were continuously hydrolyzed to poly- or oligo- peptides. Also, polypeptides may be further broken down to oligopeitides (stage II). Thus, the number of oligopeptides will have a sharp increase because each polypeptide can yield two or more oligopeptides. As a consequence, the total amount of peptides will increase since the increase of oligopeptide number overcomes the decrease of polypeptide number. Over time, more and smaller peptides will be formed increasing the number of a-AN in the hydrolysate. This will result in a larger discrepancy between the two methods.

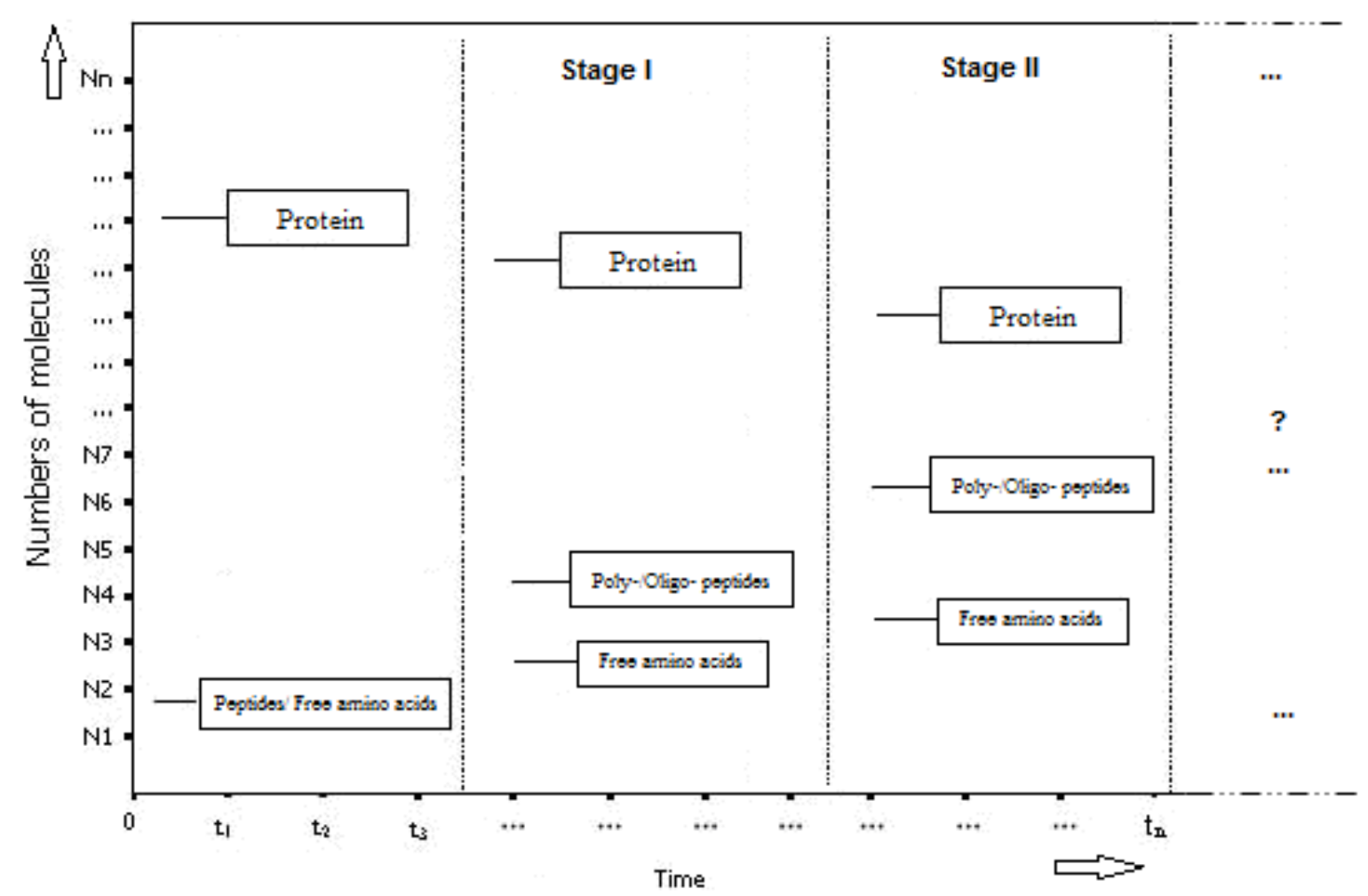

Figure 4. Schematic representation of the changes of different components (e.g., protein, poly-/oligo- peptides, and free amino acids) during the process of hydrolysis. X-axis is hydrolysis time; Y-axis is the number of the molecules

To sum up, formol titration method could detect $\alpha-\mathrm{NH}_{2}$ - group in free amino acids, oligopeptides and polypeptides in nature protein hydrolysates. As a comparison, RP-HPLC technique could only analyze the $\alpha-\mathrm{NH}_{2}$ - group in free amino acids. Thus, the amount of oligo- and poly- peptides in protein hydrolysate determined the discrepancy of the two methods on the determination of $\alpha$-AN in protein hydrolysates.

\section{Conclusion}

The formol titration technique is shown, based on the recovery rate method, to be more accurate but less precise than the RP-HPLC method in determining the $\alpha$-AN concentration in pure amino acid solutions. In terms of the application of these two methods in fish protein hydrolysates, the $\alpha$-AN concentrations obtained by RP-HPLC were much lower than those obtained by formol titration. For routine analysis of $\alpha$-AN in fish protein hydrolysate (e.g fish sauce), the formol titration method can be used as a quick screening method to assess its quality. 


\section{References}

Aspmo, S. I., Horn, S. J., \& Eijsink, V. G. H. (2005). Enzymatic hydrolysis of Atlantic cod (Gadus morhua L.) viscera. Process Biochemistry, 40, 1957-1966. http://dx.doi.org/10.1016/j.procbio.2004.07.011

Biehl, B., Brunner, E., Passern, D., Quesnel, V. C., \& Adomako, D. (1985). Acidification, proteolysis and flavours potential in fermenting cocoa beans. Journal of the Science of Food and Agriculture, 36, 583-598. http://dx.doi.org/10.1002/jsfa.2740360710

Chinese National Standard. Soy Sauce; 4235, N5006. (1994). Central Standard Bureau, Ministry of Economic Affairs, Executive Yuan: Taipei, Taiwan.

Chou, C. C., \& Ling, M. Y. (1998). Biochemical changes in soy sauce prepared with extruded and traditional raw materials. Food Research International, 31, 487-492. http://dx.doi.org/10.1016/S0963-9969(99)00017-4

Je, J. Y., Park, P. J., Jung, W. K., \& Kim, S. K. (2005). Amino acid changes in fermented oyster (Crassostrea gigas) sauce with different fermentation periods. Food Chemistry, 91, 15-18. http://dx.doi.org/10.1016/j.foodchem.2004.05.061

Kairiyama, E., \& Narvaiz, P. (1997). Decontamination of pancreatin powder by gamma irradiation. Radiation Physics and Chemistry, 49, 399-401. http://dx.doi.org/10.1016/S0969-806X(96)00149-1

Kiesvaara, M. (1975). On the soluble nitrogen fraction of barrel-salted herring and semi-preserves ripening. Technical Reserch Centre of Finland. Materials and Processing Technology Publication (Vol. 10, pp. 99).

Kim, J. S., Shahidi, F., \& Heu, M. S. (2003). Characteristics of salt-fermented sauces from shrimp processing byproducts. Journal of Agricultural and Food Chemistry, 51, 784-792. http://dx.doi.org/10.1021/jf020710j

Kim, S. K., \& Wijesekara, I. (2010). Development and biological activities of marine-derived bioactive peptides: A review. Jounral of Functional Food, 2, 1-9. http://dx.doi.org/10.1016/j.jff.2010.01.003

Lopes, A. R., \& Terra, W. R. (2003). Purification, properties and substrate specificity of a digestive trypsin from Periplaneta americana (Dictyoptera) adults. Insect Biochemistry and Molecular Biology, 33, 407-415. http://dx.doi.org/10.1016/S0965-1748(03)00003-1

Mahmoud, M. I. (1994). Physicochemical and functional properties of protein hydrolysates in nutritional products. Food Technology, 48, 89-95.

Martín, A., \& Luna del Castillo, J. (1990). Bioestadística para las ciencias de la salud (3rd ed.). Madrid: Norma.

Northrop, H. J. (1926). A convenient method for the formol titration. The Journal of General Physiology, 7 , 767-769.

Porretta, S., \& Sandei, L. (1991). Determination of 5-HMF in tomato products proposed of a rapid HPLC method and its comparison with the colorimetric method. Food Chemistry, 39, 51-57. http://dx.doi.org/10.1016/0308-8146(91)90084-2

Puig-Deu, M., \& Buxaderas, S. (1994). Analytical conditions for the determination of 23 phenylthiocarbamyl amino acids and ethanolamine in musts and wines by high performance liquid chromatography. Journal of Chromatography A, 685, 21-30. http://dx.doi.org/10.1016/0021-9673(94)00674-1

Quesada, J., Villalón, M., López, H., \& Loópez, M. C. (1995). Comparison of spectrophotometric and chromatographic methods of determination of furanic aldehydes in wine distillates. Food Chemistry, 52, 203-208. http://dx.doi.org/10.1016/0308-8146(94)P4205-T

Ren, J. Y., Zhao, M. M., Shi, J., Wang, J. S., Jiang, Y. M., Cui, C., ... Xue, J. (2008a). Optimization of antioxidant peptide production from grass carp sarcoplasmic protein using response surface methodology. LWT-Food Science and Technology, 41, 1624-1632. http://dx.doi.org/10.1016/j.lwt.2007.11.005

Ren, J. Y., Zhao, M. M., Shi, J., Wang, J. S., Jiang, Y. M., Cui, C., ... Xue, J. (2008b). Purification and identification of antioxidant peptides from grass carp muscle hydrolysates by consecutive chromatography and electrospray ionization-mass spectrometry. Food Chemistry, 108, 727-736. http://dx.doi.org/10.1016/j.foodchem.2007.11.010

Sakami, W., \& Harrington, H. (1963). Amino acid metabolism. Annual Review of Biochemistry, 32, 355-398.

Su, G. W., Ren, J. Y, Yang, B., Cui, C., \& Zhao, M. M. (2011).Comparison of hydrolysis characteristics on defatted peanut meal proteins between a protease extract from Aspergillus oryzae and commercial proteases. 
Food Chemistry, 126, 1306-1311. http://dx.doi.org/10.1016/j.foodchem.2010.11.083

Yokotsuka, T. (1986). Soy sauce biochemistry. Advances in Food Research, 30, 195-329.

Zapelena, M. J., Ansorena, D., Zalacain, I., Astiasarán, I., \& Bello, J. (1998). Dry fermented sausages manufactured with different amounts of commercial proteinases: Evolution of total free $\alpha-\mathrm{NH}_{2}-\mathrm{N}$ groups and sensory evaluation of the texture. Meat Science, 49, 213-221. http://dx.doi.org/10.1016/S0309-1740(97)00128-9 